

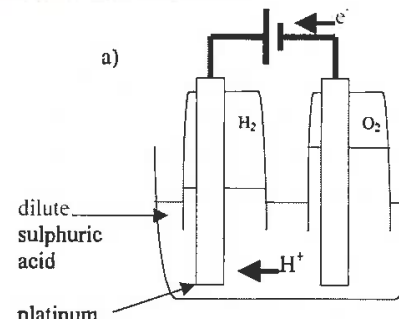

A Fig. 3: a) Grove's electrolysis experiment; b) Groves fuel cell demonstration.

using a gas engine, a fuel cell combined with a turbine can give an overall efficiency of $75 \%$, as demonstrated by Siemens Westinghouse [4]. This is significantly better than a combined cycle gas turbine generator that can typically attain $50 \%$ efficiency. And whilst such combined cycle engine systems may only operate effectively at hundreds of MWe capacity, in large centralised facilities that entail high distribution costs, a fuel cell system can operate down to $1 \mathrm{kWe}$ quite easily, be small enough to fit in every room and every vehicle, leading to a fully distributed power network.

In order to understand these high efficiencies, it is worth reflecting on the principle of fuel cell operation, which was originally described by William Grove in 1839. Following Alessandro Volta's invention of the battery, Grove like many scientists of his time was electrolysing water using two platinum electrodes dipped in dilute sulphuric acid to promote ionic conductivity in the solution (Fig. 3a). By passing electric current through the water-acid electrolyte, Grove generated hydrogen bubbles on one of the platinum electrodes and oxygen bubbles on the other. The two gases were kept separate by positioning individual collector vessels over each electrode. Grove's pioneering insight was to realise that the reaction was reversible. The hydrogen and oxygen can recombine at their respective electrodes to drive current in the opposite direction (Fig. 3b). What Grove recognised was that a fuel cell is an electrolyser running backwards. Just as an electrolyser can be made almost $100 \%$ efficient by operating near the equilibrium voltage, so can a fuel cell, as long as low currents and good electrocatalysts are used. Under these conditions, there are no pollutant emissions either, water being the only reaction product. More usually, it is practical to operate the fuel cell near its maximum power output, roughly half the equilibrium voltage and around $50 \%$ efficiency. But as electrical demand reduces, ohmic losses fall and efficiency rises, unlike a combustion engine that gets less efficient as it is turned down because of frictional losses.

\section{Technology Push}

So what has changed since Grove's time to make fuel cells more attractive than combustion engines? Obviously, legislation for zero emission has had the most significant effect, putting penalties in place for polluting companies. Another incentive is the climate change levy on fuels, introduced by the British Government in 2002, which has created a market for low carbon technologies [5]. Approximately 1 billion pounds will be raised by this novel tax this year, and some of that money will be used by the Carbon Trust to develop fuel cell technologies.

But the most important technical advance has been the invention of solid electrolytes to replace the nasty and messy liquids, such as sulphuric acid, used by Grove. Liquid electrolytes have a number of drawbacks; they leak, evaporate and corrode; whereas solid electrolytes are stable, non-corroding and self-supporting. Two materials are leading this advance. One is a polymer made

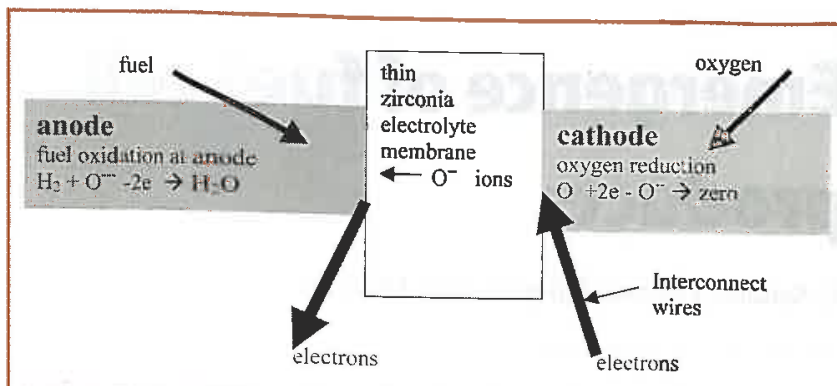

A Fig.4: Operation of a solid oxide fuel cell.

from sulphonated fluoropolymer, while the other is a ceramic made from yttria stabilised zirconia.

The mode of operation is illustrated in Fig. 4 that shows that the central component of a solid electrolyte fuel cell is a thin membrane of the solid electrolyte, typically 10 to $100 \mu \mathrm{m}$ in thickness. This allows ions to pass through but stops the flow of both gas molecules and electrons. Yttria stabilised zirconia is the simplest solid electrolyte because it only conducts oxygen ions $\mathrm{O}^{-}$. These ions are formed by reduction of oxygen atoms that pick up electrons at the catalytic oxygen electrode (cathode) which is usually a porous lanthanum manganite semiconductor. The electrons enter the electrode through a metal wire, the 'interconnect' which connects the cell to the external circuit. The oxygen ions can then diffuse through the electrolyte membrane to the fuel electrode (anode) which is normally made of fine nickel particles supported on a porous zirconia lattice. This requires red-hot conditions, typically $800^{\circ} \mathrm{C}$, for a good diffusion rate. The electrons are released from the oxygen ions and can then flow out through the interconnect wire while the oxygen reacts with the fuel, hydrogen in Fig. 1, which is continually fed to the anode compartment.

The overall reaction is the sum of the two reactions occurring on the two electrodes as shown below in reaction scheme 1 for hydrogen reacting with oxygen, the simplest reaction.

\section{Fuel electrode (anode) \\ Oxygen electrode (cathode) \\ Resultant overall reaction}

$\triangle$ Scheme 1: Two electrode reactions adding to give the complete reaction.

From this scheme it is clear that there is no product formed in the cathode compartment and only water is produced at the anode. Thus, this fuel cell is 'zero emission' as defined by US regulations. The equilibrium voltage for this reversible reaction depends on both temperature and reactant concentrations. Typically it is $1 \mathrm{~V}$ at $800^{\circ} \mathrm{C}$. Current flow of about $1 \mathrm{~A}$ for each square centimetre of membrane surface is possible, and the voltage then drops because of ohmic losses to around $0.5 \mathrm{~V}$. For high power, it is therefore obvious that the area of membrane needs to be as large as possible, $1 \mathrm{~m}^{2}$ providing typically $1 \mathrm{kWe}$. Consequently, the fuel cell design must be a stack of plates or tubular cells, similar to that of a heat exchanger or a filter, devices that also depend on high membrane area for their operation.

The conclusion is that a solid state device made up of 5 layers (electrolyte +2 electrodes +2 interconnects) can produce DC power directly without moving parts. This is almost magical in its simplicity and lends credence to the new idea that small, reliable, efficient, zero-emission power generators may develop commercially for a number of applications in the next decade. 


\section{Applications}

Already, every new car has a fuel cell built in, to control the catalyst clean-up system. This is a single cell, like that in Fig 4, comprising an yttria stabilised zirconia membrane with two electrodes and two interconnect wires, inserted in the exhaust manifold where it reaches 600 to $700^{\circ} \mathrm{C}$. On one side of the membrane is air, and on the other side is the engine exhaust stream that is deficient in oxygen. The difference in oxygen concentration across the membrane creates a voltage that depends on the oxygen level. The fuel cell therefore acts as a sensor that can be used to control the engine management system for emission catalyst performance. Only a small power is required for this task, but it is envisaged in future that the whole electrical system of the car, ie the radio, electric windows, air conditioner, etc, will be powered by a stack of such cells. In the USA there is a large development project on this theme, the SECA project, supported by Siemens, Honeywell etc [6].

Of course, it is also possible to replace the whole engine of the car with a fuel cell stack, and this has now been demonstrated by many car manufacturers using the Polymer Electrolyte Membrane (PEM) fuel cell that has been much developed by Ballard in Vancouver [7]. The PEM fuel cell uses a sulphonated fluoropolymer swollen in water to conduct proton species. Carbon electrodes with platinum catalyst are pasted on each side and graphite interconnects are generally used. Humidified hydrogen is the fuel, fed to the anode compartment and air is the oxidant, which also flushes out the product water from the cathode compartment. The temperature of operation is around $100^{\circ} \mathrm{C}$. Thus this fuel cell gives zero emissions and could provide a solution to the ZEV (zero emission vehicle) legislation. Problems of hydrogen supply are still to be overcome, as are the costs of the components compared to a standard combustion engine. However, it is estimated that a significant penetration of such ZEV fuel cells will be achieved by 2020 .

An alternative possibility has been demonstrated by BMW, who have used hydrogen as the vehicle fuel instead of gasoline. The hydrogen drives an almost standard internal combustion engine and also powers a fuel cell for auxiliary electricity. This satisfies ultra low emission regulations, although some nitrogen oxides are produced under combustion conditions. BMW also adopted liquid hydrogen storage, using cryostatic tanks in the trunk of the car, while proving that that these tanks could be topped up at robotic filling stations [8]. However, the practicality of such fuel storage is still in doubt.

The hydrogen storage issue is one of the most challenging problems in the fuel cell field. If the storage density is defined as the mass of hydrogen stored divided by the total mass of the storage system, then present methods, including hydrogen bottles and liquid hydrogen only give storage density of a few per cent, whereas gasoline is near $20 \%$. Hydrides like lithium hydride $(12.7 \%$ density) offer a possibility of improving over the present standard of pressurised bottles (about 5\%). Carbon nanotubes have been suggested as storage media, but early reports of $50 \%$ density have not been repeatable. The currently accepted value is $0.5 \%$. In order to evaluate the possibilities, a large European project, FUCHSIA has been started [9]. Hydrocarbons are still the best bet, if the carbon could be dealt with.

The most fundamental issue is the source of the hydrogen, which now is manufactured mainly from natural gas, but could be generated on board the vehicle from gasoline by means of a steam reformer. In this steam reacts with hydrocarbon to give hydrogen and CO. Unfortunately, such fuel processors are bulky, slow and expensive, and do not appear viable in the near future. A new approach to the hydrogen economy is needed where hydrogen is generated from renewable sources such as biogas, wind energy or photovoltaics. One possibility is methanol, derived from biomass, which can be used with a polymer fuel cell [10] to produce power for a laptop as shown in Fig. 5a. Also, natural gas is available in homes and could be used directly in the solid oxide fuel cell device [11] shown in Fig. 5b to provide both heat and power. This device was made using 1000 tubular zirconia fuel cells to replace the conventional metal burner in a water heater. In future, this could be augmented with biogas or renewable hydrogen to give a sustainable energy economy.

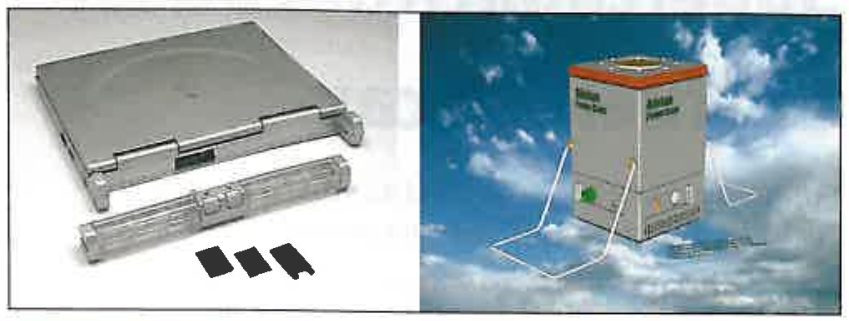

A Fig. 5: a) Casio lap-top computer powered by a PEM fuel cell fuelled by methanol; b) A solid oxide fuel cell system driven by natural gas for combined heat and power.

One exciting prospect is to generate power using such devices locally in homes. This is not yet possible with combustion engines because of their lubrication, wear, emission and ignition problems. But a small solid state fuel cell could give the reliability and lifetime needed for this application. Consider a vision of the future where each home has a fuel cell within its central heating boiler. This could run on natural gas, but also on biogas and hydrogen. Because the fuel cell is a catalytic device, without a flame, it can run on a variety of molecules, and actually runs better on diluted fuel such as biogas, whereas engines stop under these circumstances. Under base-load conditions, the fuel cell would operate at high efficiency and would also generate heat for the home. Excess power could be exported through the grid if restrictive regulations were removed. The system would be totally secure. Also, the nation's carbon dioxide emissions would be halved in the domestic and business sectors and our fuel imports reduced substantially. Totally distributed power could be achieved through fuel cells in the future. With a fuel cell in every home, there would be sufficient electricity generated without the need for large power stations.

\section{References}

[1] J.Paxman, The English, Penguin, London 1999, p.162

[2] K. Kendall, Hopes for a Flame-Free future, Nature 404(2000) 233-5

[3] S. Singhal \& K. Kendall (eds.) Solid Oxide Fuel Cells: Fundamentals and Applications, Elsevier, Oxford 2003, ch 3

[4] J.Leeper, $220 \mathrm{kWe}$ solid oxide fuel cell/microturbine generator hybrid proof of concept demonstration report, California Energy Commission, report no. P600-01-009, March 2001

[5] www.thecarbontrust,co.uk

[6] www.fossil.energy.gov/techline/t__seca_sel1.shtml

[7] www.Ballard.com

[8] www.BMW.com/bmwe/pulse/enterprise/cleanenergy2/index.html

[9] www.bham.ac.uk/fuchsia

[10] www.casio.com

[11] www.adelan.co.uk 